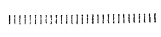
ノート

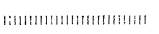

\section{ベンゼン中での石炭液化残渣 \\ の沈降に及ぼす水分の效果 \\ -1984. 7. 3 受理一}

\section{1. 緒言}

液体燃料の製造を目的として多くの石炭直接液化の 研究がなされているが，石炭を液化処理する際，石炭 液化処理物か.ら石炭の有する鉱物質・固体触煤打よび 未液化残渣物などを分離する固液分離が重要な問題で ある。これまでにも，多くの固液分離が検討されてき た1) 6)。

近年, 横内らは78), 太平洋炭, 三池炭, モーラ炭を 1, 2, 3, 4-テトラヒドロキノリン (THQ) で, 自生圧 下. $400{ }^{\circ} \mathrm{C} \cdot 10$ 分の短時間液化処理して得たベンゼン 不溶残渣 (BI) を用い，ベンゼン希薄分散系にアンチ ソルベントを添加し，重力沈降法による有效かつ効率 的な固液分離を検討した。その結果，アンチソルベン トとしては，パラフィン系炭化水素が BI の沈降を最 も促進させ，とくにnーアルカンとした場合，炭素数の 少ないるのほど分離効果が良くなった。ベンゼン希薄 分散系で BI の沈降を測定した際，測定後ベンゼン希 薄分散系での水分が減少することが確認された。この ことは, 固液分離に挅いて, 水の影響も関与している と考光られる。

そこで，本報告では，炭種の異なる石炭を $\mathrm{THQ}$

Table 1 Analysis of used coals and of benzene insoluble matter

\begin{tabular}{lccc}
\hline & \multicolumn{2}{c}{ Coal } & $\begin{array}{c}\text { Benzene Insoluble matter } \\
\end{array}$ \\
\cline { 2 - 4 } & $\mathrm{C}(\%)^{*}$ & $\operatorname{ash}(\%)^{* *}$ & $\mathrm{ash}(\%)^{* *}$ \\
\hline Taiheiyo & 74.8 & 8.4 & 76.7 \\
Miike & 85.2 & 7.8 & 75.3 \\
Moura & 87.6 & 7.1 & 32.2 \\
\hline
\end{tabular}

*; d.a.f. base **; dry base
液化処理して得た BIのベンゼン希薄分散系での固液 分離に及ぼす，ベンゼン溶液中への水の添加效果につ いて検討した。

\section{2. 実験}

\section{1 試 料}

水中保存の太平洋炭, 三池炭, モーラ炭を水洗後, 60 mesh に粉砕し， $40^{\circ} \mathrm{C} て ゙ 15 \sim 20$ 時間脱気乾燥した。 各石炭 $250 \mathrm{gr}$ V, 2 倍重量の水素供与性ビヒクルである THQ そ添加し， $2 \ell$ オートクレーブ中自生圧下で，平 均昇温速度 $2.5^{\circ} \mathrm{C} / \mathrm{min}, 420^{\circ} \mathrm{C}$ で30分处理して各液化 処理物を得た。

各液化処理物に過剩量のベンゼンを加光，遠心分離 (8000rpm，10min）によってベンゼン可溶物 (BS) と 不溶物とに分離した。この操作を上澄みが透明になる まで絽り返すことによって BS を完全に 除去して B I を得た。BIを自然乾燥後, $100 \mathrm{mesh}$ 以下儿分級し, 一週間 $107^{\circ} \mathrm{C}$ で脱気乾燥し，これを試料とした。な叔， Table 1 K太平洋, 三池, モーラの各原炭の炭素含有量 と灰分量拉よび原炭を液化処理して得た各 BI の灰分 量学示。

使用したベンゼンは，モレキュラーシーブで脱水し たベンゼン・水分 $0.016 \mathrm{wt} \%$,市販 一級ベンゼン・水分 $0.033 \mathrm{wt} \%$ ， 水を飽和させたベンゼン・水分 $0.066 ， 0.071 \mathrm{wt} \%$ を用いた。

\section{2 方 法}

B I試料を沈降管 (断面積 $1 \mathrm{~cm}^{2}$ ・ 容量 $30 \mathrm{~m} \ell)$ K, $0.5 \mathrm{~g}$ 取り,ベンゼ ソ $5 \mathrm{~m} \ell$ を加光，30分間超音波分散 をかけた後，さらにベンゼンを加 光全量30meに調製した。調製後た 


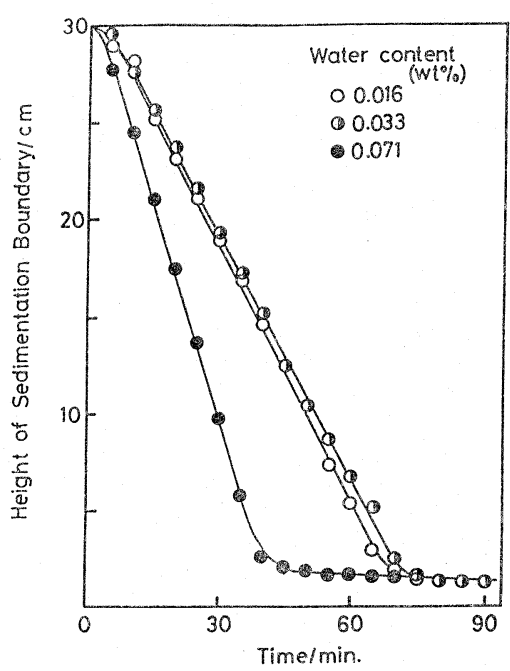

Fig. 1 Relationship between height of sedimentation boundary of Taiheiyo BI and various water content in benzene

だらに30秒振とうさせ，4時間35分放置し，その後再 び30秒振とうさせてからBIの沈降面の高さ（h）を 5 分每に90分間測定し，それよりBIの沈降速度(SR)を 求めた。

過剩量の水を含むべンゼン溶液の調製は, 水・ベン ゼンの 2 層溶液を10分間超音波分散にかけ，得られた ベンゼン層であるW/Oエマルションを用いた。W/O エマルションを所定量添加し, 同様にして, BIのSR を時間と hの変化より求めた。
ベンゼン中の水分量は，微量水分測定用カールフィ ッシャー自動滴定装置 KFA-1により測定した。各BI の比表面積は，比表面積自動測定装置2200形を用い, 窒素吸着量からBETの 1 点法によって求めた。また， 各BI の浸漬熱の測定には，双子型伝導熱量計 MPC11を用いた。粒度分布測定は, 遠心式粒度分布装置CP ー50を用いて行った。

\section{3. 結果および考察}

Fig.1 亿種々の水分量を溶解させた ゙ンゼン希薄分 散系に特ける太平洋 BI の測定時間に対するh の変化 を示す。ベンゼン中の水分が増加するに従って, BI が完全に沈降するまでの時間(ST)は減少し, SRはお の扔の増加した。この結果から, ベンゼン中の水分が 増加するに従い, 太平洋 BI の分離効果が増加するこ とが認められた。また，亳験に用いた 0.033，0.071wt \%の水分を含んだベンゼン溶液を測定終了後, 再びそ の水分を測定した結果，それぞれ0.029, 0.049wt\%と 測定後のベンゼン溶液中の水分が減少した。また，三 池 BIでは，太平洋BI同様，ベンゼン中の水分が増加 するに従い, 分離効果が増すことが認められた。一方, モーラ BIについては, ベンゼン中の水分が増加して も, ST と SR はほとんぞ変化せず, 分離効果の増加 は艾られなかった。

さらに，水を飽和量以上添加した場合の各 BI の分 離に及ぼす水の影響について検討した。用いた W/O エマルションの水分は, $0.18 \mathrm{wt} \%$ であった。このW/O エマルションを用いた結果と水を溶解させたベンゼン 溶液中で測定した結果とを併用してFig.2に示す。

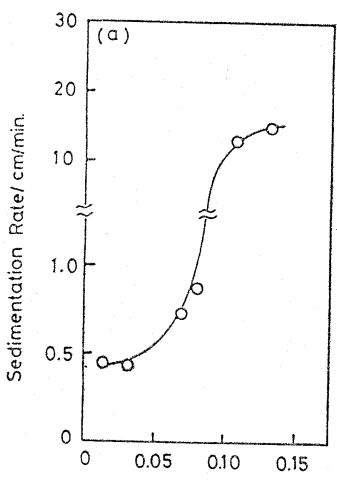

Water Content $/$ wt $\%$

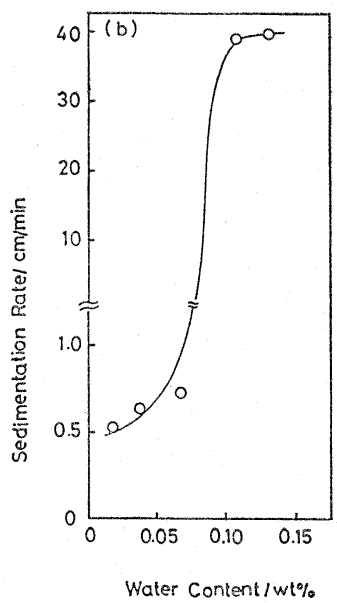

(b) Miike BI,

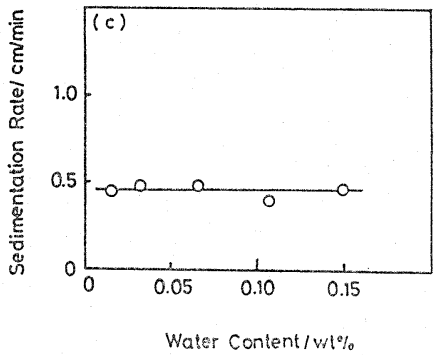

(c) Moura BI

Fig. 2 Sedimentation rate of $B I$ as a function of water content in benzene 
Table 2 Specific area and heat of immersion of benzene insoluble matters

\begin{tabular}{|c|c|c|c|c|}
\hline \multirow[b]{2}{*}{ Sample } & \multirow[b]{2}{*}{ Specific Area $\left(\mathrm{m}^{2} / \mathrm{g}\right)$} & \multicolumn{3}{|c|}{ Heat of immersion $\left(\mu \mathrm{j} / \mathrm{cm}^{2}\right)$} \\
\hline & & $\begin{array}{l}\text { into } \\
\text { dehydrated } \\
\text { benzene }\end{array}$ & $\begin{array}{l}\text { into } \\
\text { water saturated } \\
\text { benzene }\end{array}$ & $\begin{array}{l}\text { into } \\
\text { hexane }\end{array}$ \\
\hline Taiheiyo BI & 17. 13 & 9.5 & 19.1 & 14.1 \\
\hline Miike $\quad$ BI & 9.94 & 11.4 & 96.2 & 53.7 \\
\hline Moura $\mathrm{BI}$ & 10.55 & 159.4 & 234.9 & 50.3 \\
\hline
\end{tabular}

Fig.2(a)に, 太平洋BIについての結果を示す。W/O エマルションを $15 \mathrm{~m} \ell$ （水分 $0.11 \mathrm{wt} \%)$ 以上加光ること により，太平洋BIの沈降は著しく促進された。Fig.2 (b)に三池 BI そついての結果を示す。太平洋 BI 同様 $\mathrm{W} / \mathrm{O}$ エマルションを $15 \mathrm{~m}$ ( 水分 $0.11 \mathrm{wt} \%$ ) 以上加える ことにより，三池ＢI の沈降は著しく促進され，沈降 速度は太平洋 BIK比べ 2 倍以上で步った。モーラBI に関しては，Fig.2(c)に示すように,ベンゼン中の水分 が増加しても沈降に差がないことから，ベンゼン溶液 中の水分の影響をほとんぞ受けないと考光られる。

ここで，太平洋 BI，三池BIがェマルション中で著 しく沈降が促進される原因として，BI 粒子同志の凝 集が考光られる。そこで，ベンゼン中特よびェマルシ ョン中での太平洋 BI, 三池 BIの粒度分布を測定した。

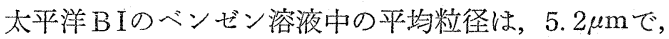
エマルション中では $6.2 \mu \mathrm{m}$ となった。また，三池BI では，平均粒径はベンゼン溶液中では $5.5 \mu \mathrm{m}$, エマル ション中では $8.0 \mu \mathrm{m}$ となった。以上のことから，太平 洋 BI，三池 BI共にエマルション中では凝集すること が確認された。BI粒子が凝集する機構は,ベンゼン中 に存在する水が BI 粒子表面の親水性を持つ灰分に吸 着し, 水の吸着膜が形成され，BI粒子同志が凝集し, BIの沈降が促進されるものと考光られる。

今まで, 親水性粒子表面への水分子の移行現象は, 浸漬熱の測定により確認できることが知られている 9)。

Table 2k各BIの比表面積特よび脱水ベンゼン中, 水を飽和させたべンゼン中，へキサン中での浸漬熱の 結果を示す。脱水ベンゼン中での浸漬熱は, 太平洋 B I は9. 5, 三池 B Iが 11. 4, モーラ BIが $159.4 \mu \mathrm{J} / \mathrm{cm}^{2}$ とな った。モーラBI に比べ，太平洋BI，三池BI の浸漬 熱が非常に小さいのは，粒子表面とベンゼンの親和性 が小さいためと考兄られる。水飽和ベンゼン中での浸 漬熱は，太平洋 BIが19.1，三池BIが96.2，モーラBI が234. $9 \mu \mathrm{J} / \mathrm{cm}^{2}$ となった。水飽和ベンゼン中での浸漬 熱が脱水ベンゼン中での浸漬熱と比べて増加するの
は, 水の BI 粒子表面への浸漬効果と考光られる。そ れぞれ，増加量は太平洋BI が9.6, 三池BI が84.8, モーラBIが75.5となり，三池BI，モーラBIは水と の浸漬効果が多きいと考光られる。しかし，水の添加 によるBIの沈降速度は, 太平洋 BI, 三池BIだけが 加速された。この沈降結果は水に上る浸漬熱の增加量 の変化では，説明できないので，脱水ベンゼン中での 浸漬熱に対しての增加率〔(水飽和ベンゼン中での浸 漬熱-脱水ベンゼン中での浸漬熱)/脱水ベンゼン中で の浸漬熱了について 検討した。増加率は, 太平洋 BI が1.0, 三池BIが7.4，モーラBIが0.5となった。こ の浸漬熱の增加率は, BI 粒子表面全体に対する水の 浸漬笴与率で，三池BIが非常に大きく，モーラBIが 小さいことがわかる。このように, この増加率はBIの 沈降速度の変化と関連づけることができる。へキサン 中での浸漬熱は, 太平洋BI 14.1, 三池BI 53.7, モー ラBI $50.3 \mu \mathrm{J} / \mathrm{cm}^{2}$ となった。へキサン中での浸漬熱 は，BI 粒子表面の無極性部分への浸漬効果と考克ら れるので，三池BI，モーラBIの粒子表面には，太平 洋 BI 粒子に比べて蹯水性な部分が多く存在するるの と考光られる。したがって，三池 BI 粒子表面には， 蹯水性な部分も存在していると思われるが，高い増加 率から判断すると乍分表面への水の吸着効果が強く沈 降に及ぼしていると考壳られる。また，太平洋 BI に 関しては, 増加率 1.0 と比較的小さいが, 他の 2 種の BI に比べて眯水性部分が少ないために, 沈降に水の 効果が大きく笴与していると考光られる。一方，モー ラBIV関しては, 增加率 0.5 と小さく, 蹯水性部分が 多く, ベンゼンとの親和性が強いため, 沈降に水の効 果がみられなかったと考光られる。しかし，BI 粒子 表面は，灰分抢よび有機物が複雑にまざりあっている ため, さらに検討の余地があると思われる。

今まで, 基礎的な観点から希薄分散系について議論 してきたが，今後は実在の系での実験および添加物と しての W/Oエマルションの安定性について検討する 必要があると考光られる。 


\section{（謝辞）}

各原炭の液化物を供給して下さいるした九州工業技 術試験所の山田泰弘氏，また浸漬熱測定に関しご協力 していただきょした東京大学生産技術研究所の萩原茂 示氏に深く感謝いたします。

\section{文献}

1）西田值矩，石炭情報（サイェンスフォーラム）第 1 集 66 (1981)，第 2 集 43 (1981)，第 3 集 61 (1981)，第 4 集 37 (1982)

2）本田英昌，燃協誌， 60，751（1981）

3）坂木 哃, 有田静児, 垣山仁夫, 本田英昌, 九工 試報告，25，1561（1980）
4）坂木 㴊，有田静児，垣山仁夫，本田英昌，九工 試報告，28，1856（1982）

5）坂木 風，有田静児，垣山仁夫，本田英昌，九工 試報告，27，1691（1981）

6）坂木 剛，有田静览，垣山仁夫，本田英昌，燃協 誌，61，34 (1982)

7）横内 敦, 河井隆伸, 江角邦男, 目黑謙次郎, 本田英昌，燃協誌，61，785（1982）

8）第20回石岸科学会議研究発表前刷集，p. 44 (1983)

9）北原文雄，渡辺 昌編，“界面電気現像”（共立出 版) p. 121 (1972)

\title{
Effect of Water on Sedimentation of Coal Liquefied Residue in Benzene
}

\author{
Masatomi Akezuma, Atsushi YoKouchi, Kunio EsUmi, \\ Kenjiro Meguro, and Hidemasa HondA \\ $\left(\begin{array}{l}\text { Department of Applied Chemistry and Institute of Colloid } \\ \text { and Interface Science, Science University of Tokyo }\end{array}\right)$
}

SYNOPSIS : - The sedimentation behaviors of the benzene insoluble matter(BI) obtained from liquefied products by the reaction of 1,2,3,4-tetrahydroquinoline (THQ) with various coals, i.e., Taiheiyo, Miike, and Moura coal, were examined in benzene by the addition of various amounts of water. The sedimentation rates of Taiheiyo BI and Miike BI were significantly accelerated by the addition of water/benzene emulsion, while the rate of Moura BI was little changed. The sedimentation mechanism of BI was discussed from the results of particle size distribution and heat of immersion of BI.

\section{Key Words}

Separation, Benzene insoluble matter, W/O emulsion 